\title{
Analytical Review of the Evolution of the Mystic Personality According to the Prose Book of Sufi at Second to Eighth Centuries
}

\author{
Fatemeh Ghafouri ${ }^{1}$, \\ Mostafa Esmaillpour ${ }^{2}$, \\ Sedigheh DehghanzadehNajmabad ${ }^{3}$
}

1- Department of Persian Language and Literature, Anar Branch, Islamic Azad University,Anar Iran.

Email: fatemeghaffuri@yahoo.com

2- PhD Student, Islamic Azad University, Anar Branch, Anar, Iran Email: e.mostafa2017@gmail.com

3- PhD, Islamic Azad University, Anar Branch, Anar, Iran, Email: sedighe13dehghanzade@gmail.com

\begin{abstract}
:
In Islamic culture, the titles of what is later called the "evolution of the mystic personality" have been raised as religious, moral and spiritual concepts in the Holy Qur'an and the Sunnah of the Prophet (pbuh), and gradually and in varying degrees in the practice of the Companions and the followers and other Muslims Then, with regard to the inner and spiritual aspect of the states and authorities, and due to changes that are created in the human soul, moral and religious concepts have been promoted to the inner paths of conduct and have covered the gospel of "mystical terms". This article aims to investigate the evolution of the mystic personality according to the narrations of prose books of Sufi from the second to the eighth century through the library method and in a historical way.
\end{abstract}

Key words: authorities, emergence, evolution, mystical terms.

\section{Introduction :}

"The evolution of the Mystic Personality" as one of the major issues in Islamic mysticism has a high position in the words and paid attention to it during the centuries. In other words, the main issues of mysticism and Sufism are status and authorities, which the seeker has to follow through the authorities through the acquisition of the right and the fullness of the truth and recognize and exploit the situations within him (Sajjadi, 1995, 735 -62). Authorities are getting on with challeng and it is a spiritual gain; but when the seeker has a talented and imaginative heart, his life is present, and this is no longer a matter of gain and rebuke, and it is the blessing of God, and that which 
comes from the outside of his beloved ones, and is like an energy that gives his heart a clear light. It will be released sooner or later (ZarrinKob, 2006: 23), whatever the blessing is entered on the pure heart of the seeker without hardship the traitor's indifference to the emergence of the traits of the soul and it is called "present" and as it became permanent. Abu al-QasimQashiri also says:" status, to the people have a meaning that enters the heart without thinking, procrastinating and gaining, such as trembling, grief, or joy, and fear. Therefore, the conditions are good and the authorities are appropriate, and the situation is without existence and the authorities are to be taken away. The difference between the words of the Sheikhs in the situations and authorities are that they call one thing status and some of them authority (Kashani, 1997: 125), even in their definition, number, arrangement and categorization in mystical texts until the eighth century $\mathrm{AH}$, there is an inconsistency and discussions and the secrets of the mystic are not in one hand.

This dispersion and disagreement is such that there is no unanimity in terms of what name and title are to be considered for each step in the course. Some have called it a tower, fountain, light, or official, and some have called it home, field and valley. This diversity of opinions on the number of civilians and officials is greater, and the distance between the different perspectives in this regard is so high that some people summarize it in three stages, and the group considers the number of stages more (Dehbashi and Mir BagheriFard, 2007: 205).

By studying the mystical sources of mysticism, this research seeks to answer the question "What are the origins of situations and authorities?" And also to examine what changes and stages, from the point of view of the emergence to the end of the eighth century, number and sequence, and whether there are points and milestones as a fundamental change in it. In addition, in present study, the similarities and differences of the mystics and its explanation are discussed. About the pros and cons of research it has to be said that the attitudes and authorities in one direction relate to theoretical mysticism which, through discovery, intuition and illumination, is based on the principles of divine religion and interprets the quality of the relation between God and man and the world, and in the other hand It is related to Gnosticism, which shows the experience of the mystics. Of course, the titles of some mystical authorities and ethical issues are also raised in ethical debates, but in this research only its mystical aspect has been considered.

Although many mystics have dealt with this issue, in spite of sharing, there are differences in terms of definitions, numbers, divisions, and so on. This raises issues and questions in the minds of 
humankind; issues such as: When has the issue and authorities been started? Who is the first person to discuss the status quo? What is the origin of the states and authorities? What is the course of development? Are there any points or milestones in its course in different ages?

At the present article, we try to find out the main ideas of the situations and the authorities by examining the narrations of the books of the Prophets of Sufism and the works of the Muslim mystics by the end of the eighth century.

\section{Source of terms and conditions}

In response to this question, what is the source of the titles and definitions of the status quo, such as repentance, patience, trust, affection, fear, certainty, poverty, humility, fear, raja, and so on? It should be said that the first source of these terms is the Quran that I recited to it, has always been with Zahad and Ta'abad Sufism, and in the first stage, there are moral and spiritual titles, and then, in the manner in which the Sufis in verses contains the words they have become mystical titles and terms. (ZarinKoub, 2006: 150-149).

\section{The time of the emergence of the situation and the authorities}

According to Abu Nasr-e Tusi, in Bab al-Zakrālī, in the book of Allah, a man rose up against Ali bin AbiTalib (AS) and questioned the faith. Imam said: the faith based on the Patience, Certainty, Justice and War in the way of God After that, he described patience as one of the tenants, and each of his beliefs and affairs in the ten states. Thus, Abu NassrSarraj states that if the attribution of that speech to the Prophet is correct, then he is the first person to know about "situation" and " authority said. (Abu NassrSarajTusi, 1380: 336).

It is mentioned in Nahj al-balaghah this tradition, with the difference in that, each of these four pillars is divided into four chapters: Patience, on four bases of craving, panic, ascetic and anticipation; certainty, on the four bases of clever insight, the reception of the wise realities, the reckoning of the events of the day, and the passing of the right path of the ancients; justice, on the four principles of deep thought, profound knowledge and truth, Good judgment and solidity in patience as well as jihad are based on the four principles of the command of the famous, the prohibition of denial, the truthfulness in any case, and the hostility with the infidels (Nahj al-Balaghah, 2003, Wisdom 31: 457) "Abdul Rahman Badavi" believes that the first person who expressed and used the word "love" in his real and personal meaning (mystical), not merely in the appearance of appearances, is "RabeaeAdāvīā" (Badavi, 1988: 75-73) but the point to be taken into account in this regard is that it should be clarified, when exactly did Rabaie survive? If the year $185 \mathrm{AH}$ is accepted as the year of Raba'a's death, the correctness of Abd al- 
Rahman al-Bada'i is doubtful because the Zahedān and Sufis before Rab'a's have been quoted as saying that they are said to be divine with the special meaning of self-denial (Dehbashi, MirbagheriFard, 2007: 61) Abdul WahdbnZayed was one of the first to raise the issue of love between created and God (Shimmel, 1995: 82).

\section{Condition in the term of Mysticism}

The mystics have presented a number of different definitions of the present: "Janeed Baghdadi", who in mystical texts identified with many names such as Seyyed al-Tayyaf al-Qum, the Prophet, one of the pillars of Islamic Sufism is considered, in the definition of the present says: "Now, it is the words of the descendants which descends in the hearts and does not endure (Atar, 1995: 445), and somewhere else He says: "of being a bridegroom who is coming and going, and whatever remains, it was not that he was a hadeeth of soul and soul" (Hajviari, 1997: 226-224). "Abu Bakr Wasati" Death: 320 AH): "Now, it is to be able to heal time from time immemorial to the unbelievers," says the singer and son of Baghdadi, whose mystical line follows the mystical line of the Qingdae of Baghdad. (RoozbehanBaghiShirazi. (1995) A description of Shatihyat to correct Henri Carbin. Third edition. Tehran: Taheri.1995: 546) Abu Nasr-e Tara-e-Tusi, known as Tavous Al-Abira and the owner of the Book of Allah, in the present definition, states: "Meaning that enters into the heart of the seeker without the discretion and intention, attraction and acquisition, such as tortures or griefs and expansions or pleasures and enthusiasm, and the like, etc." (Ghani, 2004: 284) Another mystic has said: "Now, it is that it is sent down from the Lord by the servant of the Lord; therefore, it is a type of divine inspiration and is from divine mercy." He has called "KsootAbudit" (Bukhari, 1987: 2296).

In the discovery of Al-Muhajib, this is now defined: "It means to belong to the right without having to afford it to be dispossessed, because it comes or can be attracted to it, because it is gone and now it was From the grace of God, his excellency, weltfahr to his heart, his disobedience to his mind, and now, from the best of his grace, he was mortal." (Hajviari, 1997: 226-224) Abolqasem Qashiri, of the great mystics of the fifth century, also says: "Now, close to the people, it means meaning to fall into the heart without having them He was an affair, and it was either happiness or sorrow, or expense, or a pursuit, or affection, or movement. The status, the business and the status were the same, and the authorities did not care about it. "(Ghashiri, 2000: 93-92). In the definitions that the mystics have presented to the end of the fifth century of" present" there are two attributes of divine gift and instability.

The same definitions have been accepted and repeated in many works written after the fifth century, including "Abdul 
RazzaqKashani" (816-887), in the Sufi terms: "Now, the meaning is that immediately upon the heart, without intention, intention and without acquisition." Also, in Mesbah al-Hadayeh and Moftah alQufa'i, the following is now defined:" Now, near the Sufis, there is an incident that is not known from the Alawite universe at times he descended to the heart of the slaughterer and came to the door until he was brought to the clergy by the divine attraction from the position of Ondani"(Kashani, 1993: 125). According to Ibn 'Arabi," It is now entering a heart of grief Outs In other words, the status is a blessing that is given to the servant by the Lord, or with the pleasure of doing something pure and full of soul, on his heart or from the direction of the great god"(Sa'idi, 2004: 206).

Contrary to the view of Janet Baghdadi, who believed that "present" does not exist, but sometimes it turns out to be a source of power, some others, according to HarithMohassabi (died: $243 \mathrm{AH}$ ), have said that survival is possible. (Ghani, 2004: 193-192). Another difference between HarithMoustabi and Janeed Baghdadi is that "HarithMohassefi does not say inappropriately among the authorities; he says that it is one of the circumstances, and it is the opposite, then the people of Khorasan promised that Jenid Baghdadi and the Iraqi people said that Reza is the authority of the authorities and that it is the ultimate trust, and until today, there is a difference between the people (Hajviari, 1997: 219).

\section{In the definitions given in the article, there are a few important points:}

1- In most of the definitions given, the status is the kind of divine gift that God sends down to the heart of the individual.

1. They are not durable, and as electricity will be lost after an hour.

2. It can be said that in the famous definition of the present, the qualities of the soul descend from the Lord BiddelSalek, and is not at the discretion of the Saleker, and that it does not have any effect on its repulsion or its absorption, and it is such as good, not compassionate and powerless. Come and go

3. As mentioned, Janet Baghdadi, Abu Nasr SerajTusi, Hajvi and many others have accepted this definition.

4. Janeed believes that now, it is not sustainable, including officials. Some people like HarithMoussebi and Abu Sathman Hari, believe that they are lasting and that Reza is one of them. The phrase quoted from the virtue indicates that virtue before the Harith of computation conceived of Reza as one of the human beings.

A comparative study of the views of Abu NasrSeraj and Khawaja Abdollah Ansari in Ahwal 
Considering the notable efforts of Abu Nasr SirajTusi and Khaje Abdullah Ansari in discussing civilizations and officials, we are going to examine the comparative views of these two mystics.

Abu Nasr Seraj Toosi, the fourth Arif and the author of the authentic book and Encyclopedia of the Holy Spirit, divided the status into ten divisions: care, affection, affection, fear, raja, enthusiasm, anis, confidence, observance and certainty (Abu NasrSeraj, 1373: 242260), and for each one of them, he has three grades: beginners, middle and graduate grades. This categorization is based on the presence of a seeker in the beginning, middle and end of the course. If the seeker is at the beginning of his course, he is beginner, and if he is in the middle of the course, the medium or real, if at the end, is called mystic.

Khajeh Abdullah Ansari, one of the great mystics of the fifth century AH and the owner of Al-Sa'erin's House, also believed in the ten: love, neglect, enthusiasm, enthusiasm, thirst, excitement, despair, excitement, electricity and taste. (Khwaja Abdullah Ansari, 1994: 215) From the comparison of the number of generations, according to Abu Sasser Saraj and Khawaja Abdullah, it is clear that:

1. Divide the two segments to ten part;

2. The second part of the two is that they are only in common (love and affection);

3. The third is that they are called three degrees for each of them, with the difference that Abu PrasrSaraj calls these three degrees as beginners, middle class, and mothers, but Khwaja Abdullah, these three degrees are popular, Seeker and Reasonable. As a result, they have increased both the number of people to 30 , which is why the grace is superior to SiraiTusi.

But the important differences between the two in the context of the situation are that eight of the cases mentioned in Allaam are not in alSa'irin's homes, and eight in the al-Sa'irin's homes are not in Allah. Another is that Abu Nasr takes care of the first time, while Khaje Abdullah introduces love for the first time. Abu Nasir knows the last thing, but Khwaja Abdullah, the last taste. Ultimately, Abu Nasr considers the last thing to be true, but Khwaja Abdallah, the last taste. Finally, Abu Nasr Seraj brought the discussion of the situation in one of the sections of the Book of Allah, called "The Book of Allah, and the Governors," while Khwaja Abdullah independently discussed the situation in the book Al-Saerin's Houses in one of the Ten Sections Has raised.

\section{Authorities in the term mysticism}

According to the Abu Nasrar, SirajTusi, "The servant in the presence of the divine god is in the worship and prayer of the Qur'an of Allah" (Seraj, 1373: 229). After the first place, he considers each 
position as the result of the previous authorities, and the authorities are ethical exercises and practices The conduct of Sufi orthopathy is from the acquisition and acquisition of affairs, including acts and under the authority of the Salek (Ghani, 2004: 193-192). In the same vein, Abu al-Hassan Hjewiri states: "The official was the way of his bid and his endorsement of the place of ijtihad and in his direction, to the extent of his commitment to the Prophet, he is the Exalted. Hajviari, (1997: 225) believes that the position is one of the actions and compositions, and now, among the benefits. So, the owner of the authority, is your own authority, and the author of the present is a mortal himself. He is the one who created him in the name of Allah (Sajjadi, 1995: 739).

AbolqasemQashiri also defines the position that "the position was that the servant should be realized and the position was desirable, and that the position of each person was standing close to him, and that which would come to him" (Qashiri, 1379: 92)

\section{The points that are derived from the mystical definitions are as follows:}

1. There is a close connection between the definition of the position (position, position and place of revolt) with its defining term. From its lexical meanings, the "site of the uprising" is close to the definition of Abu Sasser, SirajTusi, and has a meaningful relationship with the term definition.

2. The position is obtained through austerity and is made possible by an extreme effort and, therefore, is a component and not a blessing.

3. It does not accept deterioration, but the existence of a slaughterhouse is the place to seize it and it lasts.

Regarding the transformation of the present to the position, it is true that the state of affairs has an inactive and enduring spirit. But as they repeat themselves and reappear, the mystic recognizes them and their constant repetition, for his sake, is all the more meaningful. To be According to Sufism, gradually it has become a position and is being rebuilt. Of course, through care and attention, and gradually, it has become a position and resigned. Of course, it is possible to rehabilitate and restore this condition by means of care and assistance, with the help of the repetition of certain movements, as well as with the seclusion and asceticism. (ZarrinKoub, 2006: 12-11)

\section{Number and order of officials}

Each of the mystics has referred to the purposes, stages, homes and authorities for their purposes and their views in this regard. The opinions of Imam Ja'farSadiq (AS) (martyrdom: $148 \mathrm{AH}$ ) about the houses of the garrison of Wislak are quoted in the commentary attributed to them in Salmi's "truths of clarity". In the interpretation of several verses, Imam has expressed the stages of the Anfisa and the way through various names; among them, in the interpretation of the 
verse "Tabarak al-Zahi al-ha'îf al-sāmabraja" (Frqān, 61), Sama is a metaphor from the heart and for that, Two aspects have been expressed:

One is the fact that the sky is lofty that has been surrounded by the universe, and can also come to life with the help of faith and knowledge, and rise to infinity. Secondly, as there are twelve towers in the sky, and the regime and the world are dependent on them, the human heart also has twelve towers, which, if these twelve towers appear in their hearts, are obtained by Salah. Each of these towers is a home and a kind that the seeker can achieve. These twelve esoteric towers are: faith, knowledge, intellect, certainty, Islam, Ehsan, Tavakol, Dare, Raja, love, passion and vele (Pourjavadi, 1369: 46).

Paul Novia says: Imam Sadiq, in his commentary, discovers the twelve springs by contemplating the stone that Moses from the water flooded for his people: "O Muhammad al-Musa'at al-Husayn alHayum al-'Abn al-Bāṣāq al-Hīr '(As the people of Musa asked him for water, We rebuked him to throw a stone on the stone, twelve springs flowed from that stone.

From the knowledge, twelve springs flowed so that people of every degree, in their place and in their souls, would drink from one of these springs. The first source is the vision of monotheism; secondly, the vision of servitude and servant; third; the sight of sincerity; the fourth; the vision of truth; the fifth; the vision of humility; the sixth, the vision of the word; the seventh; the fountain of contemplation; the eighth; God; ninth; the vision of certainty; the tenth eye of reason; the eleventh eye of the love; the twelfth; the eye of the human and the ignorant and the spring; the knowledge itself of which all these springs are boiling. One who draws from one of these springs, he thinks about it and raises his eyes and thus goes from one source to another, reaching the principle and reaching the principle, he realizes in the right (Neva, 1994: 142-141).

Shashiq Balkhi is another mystic who deals with the division of officials and houses of worship. Paul Navia has denied that the originality of this treatise cannot be ruled out of a treatise titled ShatiqBalkhi in a linear edition of Istanbul entitled "Adab al-Abadat". He says: "The documents" is the same as that which narrates the basis of a part of the narrations of Shāqiq, written by Halea al-Awlia (vol. 8, 57-73).

Abu Sa'idKharaz, in the third AH century, says in his al-Sufat book three houses for a sailor: 1. Prayer: In this home, he cares for the soul and the soul; in his speech and silence, in The full attention is to God; (2) In this house, the soul is in fear that God will veil the veil on one side and choose its own chosen one, for the god "who has been found" is the essence of the cripple that is a spectacle of fear. Then the 
Sufi may have experienced a "wave" or a horror that would overwhelm his soul. At this point, when even the elders of the path of action begin to shout, they will surely lose their hearts and minds, especially the disciples. Others are tearing and shouting; therefore, the house of despair is a scary stage that examines the sensitivity of man; 3-forgetting: at this home, man is approaching his inner transformation because God's eyes on him, in the roots of what the person it consists of "memories", it strikes, and not only does not forget what God wants or what he desires, but, in addition, he forgets God's memory and can no longer remember God. To find him through science. At this stage, God is present in his servant, but the servant is absent and not in between. Kharaz says: "God's blessing brings him out of the remembrance of God (Neva, 1994: 214).

Certainly, others, especially the disciples, are calm and losing. Others are tearing and shouting; therefore, the house of despair is a scary stage that examines the sensitivity of man; 3 -forgetting: at this home, man is approaching his inner transformation because God's eyes on him, in the roots of what the person It consists of "memories", it strikes, and not only does not forget what God wants or what he desires, but, in addition, he forgets God's memory and can no longer remember God. To find him through science. At this stage, God is present in his servant, but the servant is absent and not in between. Kharaz says: "God's blessing brings him out of the remembrance of God (Neva, 1994: 214).

In the book "Sierra'lam al-Nablah", the homes of the clerics named Kharaz called them: "Repentance, Fear, Raja, the authority of the righteous, the Meridian, the authority of the authorities, the authority of the Imperial, the enthusiastic position, the position of AlAlawiya, the office of the mercenaries.

"AbolhosseinNoori" introduces three stages for the Syrosluq. Oder considers his view of the celestial seal to God to be maritime trips that the sailor must pass from three seas in order to reach the right: 1) the lordicity of the 2nd grace of magnetism 3) the sea of lachotite.

1- The Sea of Lordship: In this sea, the man is godly and God is the Passover. So, Del Salek, he dreams in the sea of thought, and his tongue recalls the blessings of God, and he is engaged in serving and seeking the satisfaction of God. In this case, it is desirable to obey the law of the sea and to serve the ceasefire and its pollution, and to heed the divine blessings that will lead him forward, and drive your face down the ship, which winds on the ship and throws it into the sea of majhimity Pulls

2. Sea of Mayhemite: In this sea, God is the protector of Mahiān. At this stage, the ship does not work, but it is made up of a passion and passion, and the human being cares for the human being, through 
which man returns to the house through repentance, enthusiasm and affection.

3. Lagoitte Sea: At this stage, the sea-lodge arrived at sea, not a spacecraft, nor a bridge, and only a way for it to reach a coast of the sea, and it should be laid down in the water until the wind Peace be upon him and bring him to the shore, and this is where he finds the greatness of the Almighty God.

Abu Bakr Wasati also used the parable of the sea and the tower, the stages of conduct and their number are four: the authority of the winner is four: Dhahl, astounding, Saker, Sahwa. He qualifies in passing these officials to someone who first listens to the name of the sea and then approaches it and then falls into it and eventually throws away his waves; in this case, the seeker has reached the goal. (Suhrawardi, 1995: 193).

Muhammad Ali Hakim Tarmazi, in his famous book, "The End of the Awlia," in the words of the houses of conduct. The fourth chapter of this book, in the answer to the question "The queue of Lena Mahesh al-Awlia Aza, my Number? A strange and distinct comment from other mystics about the number of homes. He considers the number of these houses twenty-four thousand eight thousand and categorizes them in three categories:

First, middle and late breaks. One hundred and thirty thousand and thirty-five homes are devoted to the middle floor, and the other houses are divided into two other classes. In the answer to this question, Tremzie also divides the houses from two directions into two sensory and semantic groups. The senses in the world are regarded by the same mystical being that the seeker can do extraordinary things through them, and he considers the sense of life in the hereafter as paradise, which itself is one hundred degrees. There are more than one hundred and ten houses in each of the two worlds, in which every home has its own other home. The homes of the two hundred and eighty-four-man homes are not available to anyone before the Ummah of Islam.

1- The Sea of Lordship: In this sea, the man is godly and God is the Passover. So, Del Salek, he dreams in the sea of thought, and his tongue recalls the blessings of God, and he is engaged in serving and seeking the satisfaction of God. In this case, it is desirable to obey the law of the sea and to serve the ceasefire and its pollution, and to heed the divine blessings that will lead him forward, and drive your face down the ship, which winds on the ship and throws it into the sea of majhimity Pulls

2. Sea of Mayhemite: In this sea, God is the protector of Mahiān. At this stage, the ship does not work, but it is made up of a passion and passion, and the human being cares for the human being, through 
which man returns to the house through repentance, enthusiasm and affection.

3. Lagoitte Sea: At this stage, the sea-lodge arrived at sea, not a spacecraft, nor a bridge, and only a way for it to reach a coast of the sea, and it should be laid down in the water until the wind Peace be upon him and bring him to the shore, and this is where he finds the greatness of the Almighty God.

Abu Bakr Wasati also uses the parable of the sea and the tower, the stages of conduct and their number are four: the authority of the winner is four: Dhahl, astounding, Saker, Sahwa. He qualifies in passing these officials to someone who first listens to the name of the sea and then approaches it and then falls into it and eventually throws away his waves; in this case, the seeker has reached the goal. (Suhrawardi, 1995: 193).

Muhammad Ali Hakim Tarmazi in his famous book, "The End of the Awlia," in the words of the houses of conduct. The fourth chapter of this book, in the answer to the question "The queue of Lena Mahesh al-Awlia Aza, My Number?, A strange and distinct comment from other mystics about the number of homes. He considers the number of these houses twenty-four thousand eight thousand and categorizes them in three categories:

First, middle and late breaks. One hundred and thirty thousand and thirty-five homes are devoted to the middle floor, and the other houses are divided into two other classes. In the answer to this question, Tremzie also divides the houses from two directions into two sensory and semantic groups. The senses in the world are regarded by the same mystical being that the seeker can do extraordinary things through them, and he considers the sense of life in the hereafter as paradise, which itself is one hundred degrees. There are more than one hundred and ten houses in each of the two worlds, in which every home has its own other home. The homes of the two hundred and eighty-four-man homes are not available to anyone before the Ummah of Islam.

Khwaja Abdullah published the book of al-Sa'irin's houses in $475 \mathrm{AD}$. AH, meaning 27 years after the hardship, has been written in Arabic. The author in this book places the authorities and the houses in ten parts that represent the principles and the principles that begin with the development and end with the end. Each of these sections itself has ten bobs, and thus, the book is a total of 100 bobs. The contents of each of these verses are in their turn set at three levels: the degree of the public, the degree of the seeker, and the extent of the scholar (Khwaja Abdullah Ansari, 1994: 12-11). 


\section{The differences between the discussions was as following:}

1) Abu-Nasr considers the authorities as seven, and since he named three positions for each position, without having been able to name all the authorities, he increased the number of officials to 21 , while Khwaja Abdullah in the Hundreds, he lists 100 officials and places ten for each position, but does not name them, and in the houses of alSaerin, he places officials in 10 sections each of which has 10 bonds, which in total, It contains 100 bobs, and for each of these bows, in its turn, it has set three degrees and thus, without having been able to name all the authorities, Don, officials and home to thousands of officials Sayerin to 300 patients.

2. Another difference is that Abu Nasr Sarah brought the discussion of the authorities to one of the sections of the book, "The Book of Allah, and the Governors," while Khajeh Abdullah has raised the discussion of the authorities independently in the book of Hadith and Homes of Al-Sa'erin.

3. The other difference between these two is that Abu Nasr considers the first official to repent if Khwaja Abdullah introduces the first position at the Al-Saerin House.

4. Abu Nasir considers the last position as trust, while Khwaja, the servant, declares the last authority as love, and declares the monotheism in the al-Saerin's house.

5. Finally, Khwaja points out that the people who are in these authorities are very diverse and there is no consistent and decisive role for all of them, whereas Abu Sasser Saraj, in this regard, makes some kind of logical dedication; any previous member requires the next position.

\section{The results of the mystic's opinions on the authorities are as follows:}

1. In relation to the houses and the stages of the procedure, there is a dissenting discrepancy; in such a way that there is no theoretical unity in naming the stages of the course of the journey, and uses different titles such as the tower, the spring, the house, the sea, the position and the field. And at the same time, with all the differences of opinion, with tolerance, among these titles, the two titles "home" and "authority" can be named, because they have been used more mystically until the end of the fifth century, as the name of each stage of selected route.

2- There is inconsistency about the number of officials in the mystic works until the end of the fifth century $\mathrm{AH}$, and the mysteries in this relation are not uniform and coherent; in such a way that a group of these houses and offices are three houses and a group, four houses and some two to twenty four thousand and eight thousand Home. 
3- Despite the differences between the mystics in the number of officials, Yahya bin Mu'atzRazi, Abu Sa'idKharraz, Abu NasrazatTusi, Abu Talib Maki, AbulhassanHajviary, AbolqasemGhashiri, Abu HamedGhazali and Khawaja Abdullah Ansari (in the Hundreds of Sadis) believe that the first official is repentant, Kelabadi believes that the first official is ascetic.

4. ShatiqBalkhi, Abutaleb Maki and Khawaja Abdullah Ansari (in the Treatise of the Sadducees) share the view that they are the last authority of kindness.

5- In the study of Imam Sadegh from two different verses regarding the placement of 12 houses and various stages; they share the wisdom, certainty, trust and goodness of each other; and the three houses mentioned in the first verse are not in the second, and the other in the second verse there is no such thing in the first; therefore, if the correctness of the interpretation of the verses is attributed to the Prophet, some examples of the houses and mystical authorities associated with the verses are mentioned, and the houses and authorities are not limited to a certain number.

6- By the end of the eighth century, the only mystic who separated the status from the authorities and made a distinct one for each one, and divided it into a separate form, apart from other matters, the fourth century Sufi, Abu NassrSarajTusi, Is. After him, Khajeh Abdullah Ansari also paid attention to this division to some extent in the houses of Al-Sa'erin.

\section{How to advance from authority to higher}

Passing through a position to a higher position, all the mystics agree that they must start from the primary authorities (for each mystic of these officials), to the middle officials and, from there, to higher officials. But whether it is possible for a seeker to correct the position that he has in front of him before he can advance to the above position, the mystics disagree. Joneyd said that the servant may advance to a higher position before that he will finish the first place, but the rest of it remains, and if he moves to a higher position then he will inform the official and correct it. (Sajjadi, 1995: 309, and Kashani, 1993). In fact, he has allowed him to pass over a position to a higher position. But in the fifth century, Abu al-Hassan Hajviri believes that: "It is upon the servant to observe the right of the authority to understand its perfection; as it is written, it is not for a person who has to go from his position without leaving the right and put it ; As if the authorities were repentant, then he would be defeated, then he will, then there is no need to believe in such a claim that if he does not repent, he will challenge the lawsuit, and he will reject the lawsuit "(Hajviri Ghaznavi, 1997: 226-224). AbolqasemQashiri, the fifth-century mystic, confirms the hijauri's words and says: "The 
condition was that from this position, to another, until the judgment of this position, all of Nard; instead of respecting anyone, his true trust and nobody who was in trust, his surrender would not be correct" (Ghashiri, 2000: 92). Thus, Khajeh Abdullah, on the other hand, believes that, in order to avoid a person to a higher position, he cannot give the right to the previous position correctly.

\section{Conclusion :}

Because of the importance of the discussion of situation and authorities, many mystics have dealt with it; a group has only named its titles and terms in its own words, and a brief account is given of it, And another group, in their works and collections, are divided and the group has also done a great deal to bring it together. By reviewing their opinions and their works, the following results are obtained:

1. The part of the lexical definitions is closer to the current term definition; also, despite the many definitions that the mystics have presented of the status and authority, the definition adopted by the majority of them can be accepted, and it is considered a well-defined definition of these terms. . In this way, the condition is a kind of divine inspiration that is revealed by God on the heart of the seeker and as electricity, and he will soon be forgiven. And the position is a matter of compassion that the slave gains in its effort and hard work.

2. The root of the terminology and the title of situation and authority should be from Quranic verses and hadiths, as the mystics themselves have mentioned.

3. The history of the discussion of the status and authority of the first half of the first century AH comes and the first person who has discussed the situation and authorities is Ali (AS).

4. Most of the mystics from the early centuries to the eighth century did not have systematically categorized and numbered the number and extent of each individual, and each has been referred to some of the terms in everyday life. Of these mystics, only two Aref (Abu Nasr SerajTusi and Khajeh Abdullah Ansari) have separated the present and discussed it in greater detail.

5- Comparison of the authorities from the viewpoint of the great fourteenth century and the fourth century, ie, Abu Sasser Saraj and Khawaja Abdullah Ansari, that each of the seven officials mentioned in al-Lahm is mentioned in the Hadith and Al-Sa'erin. Abu Nasr considers the first official repent and Abdullah also repents the first official. Both are three degrees for each official.

6- According to the above, the most important and most important development in the discussion of mystical authorities from the 2nd to 8th centuries was by Abu Nasr Sarah in the 4th century and by Khajeh Abdullah Ansari in the 5th century, and each by the time he developed and evolved considerably Have given away. Therefore, the fourth and 
fifth centuries are considered to be the milestones of the mystical authorities.

\section{References:}

1. Sajjadi, SeyyedJafar (1995) Dictionary of mystical expressions and expressions. Sixth edition. Tehran: Taheri.

2. Zarrinkoub, Abdolhossein. (2006) Searching Sufism. Eighth edition Tehran: Amir Kabir

3. Kashani, Abdul Razzaq (1997). The terms of Sufis, translated by Mohammad Ali Mododalari. Tehran: Sura.

4. Dehbashi, Seyyed Ali AsgharmirBagheriFard (2007). The history of Sufism 1. Second book. Tehran: Position.

5. SerajTusi, Abu Nasr. (1994) Al-Lamfi Al-Tasouf, corrected by Nicholson. Translation by ghodrat Al-AlahKhayatanand Collaborators. In vain Publishing feyz.

6. Nahj al-Balaghah, translation by Mohammad Dashti. (2003) Qom: Holy Mosque of Jamkaran.

7. Badavi, Abdul Rahman (1988), Shahideeshgheelahi, RabeaeAdwiya, Translation by Mohammad Tahirirchi. Tehran: Molly.

8. Shimmel, Anne Marie (1995). The mystical dimensions of Islam, translated by Abdul Rahim Guahi. Tehran: Publishing House of Islamic Culture.

9. Atar Neyshaburi, Sheikh Farid al-Din, 1995, Tazkera al-Awlia, Corrected by Mohammad Eslami, Eighth Edition, Zwar Publishing.

10. Hajviari, Abolhassan Ali ibn Usman (1997), Kashif al-Mahjub, to correct Józkówski. 5th edition: Tahori.

11. RoozbehanBaghiShirazi. (1995) A description of Shatihyat to correct Henri Carbin. Third edition. Tehran: Taheri.

12. Bukhari, Abu Abraham Ismail ibn Muhammad (Imam) (1987)sharhe altaraflemazhab al-tasavofWith the introduction, correction of Mohammad Roshan's athletics. C3. Tehran: Mythology.

13. Ghashiri, Abolghasem (2000). Resurrection of Ghashiriyeh, translated by Abu Ali Othmani, to correct Badi 'al-Zaman Foruzanfar. Sixth Edition. Tehran: Academic Publishing Company.

14. Sa'idi, Golbaba (2004). FarhangeEslahat of Ibn Arabi. Tehran: Shafiei

15. Ghani, Qasim (2004). The history of Sufism in Islam. Ninth edition C 2. Tehran: Zawar.

16. Khwaja Abdullah Ansari (1994). sharhemanazel Al-saerin. Writing by Ali Shirvani. Tehran: Al-Zahra.

17. Neva, Paul (1994) The Quranic Interpretation of the Mystic Wisdom. Translation by Ismael Sa'adat. Tehran: Academic Publishing Center.

18. Suhrawardi, Shahabuddin Abu Hafz Omar (1995). Avaref Al-maref. Translation by Abu Mansour Abdul Mu'manIsfahani. In addition to the introduction of Qassim Ansari. Tehran: Scientific Cultural Publishing. 


\section{دراسة تحليلية لتظور الثخصية الصوفية \\ حسب روايات الكتب النثرية للصوفية \\ من القرن الثاني الى القرن الثامن للهجري}

فاطمة غقوري، قسم اللغة الفارسية و آدابها، جامعة آزاد الاسلامية .فرع انار، ايران

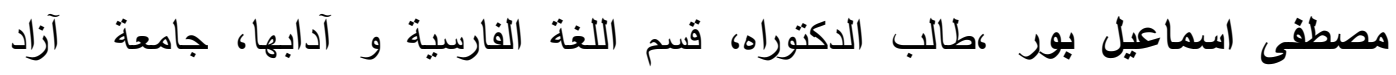
الاسلامية .فرع انار ، ايران

صديقه دهقان زاده نجم آباد، طالبة الدكتوراه، قسم اللغة الفارسية و آدابها،جامعة آزاد الاسلامية ـ فرع انار، ايران

الملخص:

في الثقافة الإسلامية ، تُعرض مفاهيم ما تسمى فيما بعد ب"تطور الثخصية

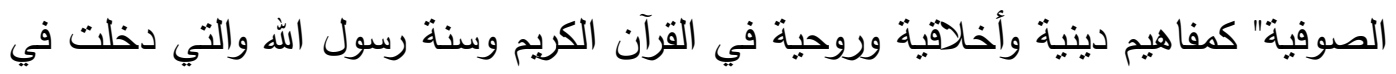

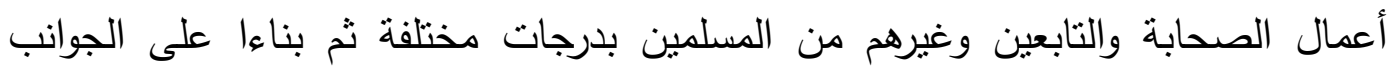

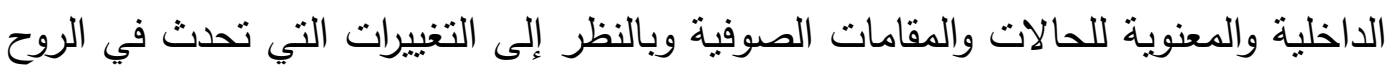

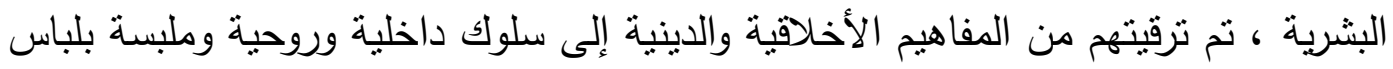

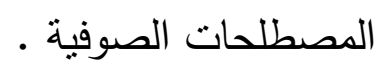
تهدف هذه المقالة إلى دراسة تطور الثخصية الصوفية حسب روايات كتب إثبات الصوفية من القرن الثاني إلى القرن الثامن من خلال دراسة المصادر التاريخية و الكتب الصوفية الموجودة. - المن

الكلمات المفتاحية: الأحوال الصوفية ، المقامات ، الظهور ، النطور ، المصطلحات الصوفية 